\title{
IN VITRO ANTI-INFLAMMATORY AND CYTOTOXICITY STUDIES OF TWO MANGROVE ASSOCIATED LICHENS, Dirinaria consimilis AND Ramalina leiodea EXTRACTS
}

\section{VINAY BHARADWAJ TATIPAMULA* AND GIRIJA SASTRY VEDULA}

\author{
Pharmaceutical Chemistry Department, University College of Pharmaceutical Sciences, Andhra University,
} Visakhapatnam - 530 003, Andhra Pradesh, India.

Keywords: Inflammation, cancer, protein
denaturation method, SRB assay,
cytotoxicity
Correspondence:
Vinay Bharadwaj Tatipamula M.Pharm, Ph.D
Pharmaceutical Chemistry Department,
University College of Pharmaceutical Sciences,
Andhra University, Visakhapatnam,
Andhra Pradesh, India. - 530 003
Received: 15 April 2018,
Revised: 9 May 2018
Accepted: 28 May 2018,
Available online: 15 September 2018

\begin{abstract}
Plan: To evaluate the anti-inflammatory and cytotoxicity activity of different extracts from two different manglicolous lichens (Dirinaria consimilis and Ramalina leiodea).

Preface: Inflammation is the origin of several deadly diseases like cancer, atherosclerosis, Alzheimer's and rheumatoid arthritis. From decades, lichen extracts and its metabolites are well known in treating inflammation and cancer.

Outcome: The outcome of protein denaturation method confirmed that the ethyl acetate and acetone extract of $R$. leiodea depicted better inhibitory profile against protein denaturation with IC $C_{50}$ values of 268 and $330 \mu \mathrm{g} / \mathrm{mL}$ Furthermore, the results of SRB assay showed that ethyl acetate and acetone extracts of both the lichens acts potently against MCF-7, DLD-1, HeLa and A549. Simultaneously, all the tested extracts depicted low degree of specificity towards NHME, they are less toxic. Hence, further screening of these extracts may lead to the exploration of safe and potent anti-inflammatory and anticancer agents.
\end{abstract}

\section{INTRODUCTION}

Inflammation is a response to any sort of physically contusion like injured cells, pathogens or irritants ${ }^{1}$. Inflammatory process which under usual conditions is self-limiting becomes continuous and chronic inflammatory syndromes flourish eventually ${ }^{2}$. The chronic inflammatory syndrome leading to dangerous diseases like appendicitis, bronchitis, dermatitis, meningitis, sinusitis, sore throat, tonsillitis, aging, Alzheimer's, asthma, atherosclerosis, cancer, Crohn's disease, hepatitis, peptic ulcer, periodontitis, psoriasis, rheumatoid arthritis, sclerosis, sepsis and tuberculosis diseases ${ }^{3}$.

(c) All rights reserved Hygeia journal for drugs and medicines, 22293590

ORCID ID: 0000-0002-9376-1911, Researcher id: L-8352-2018 
Earlier, steroidal and non-steroidal anti-inflammatory drugs are used to manage inflammation in the human body. Besides the pharmacological activity of these drugs several side effects include bleeding, gastric ulceration and hypertension were noticed. In addition, long term usage of these steroidal and nonsteroidal anti-inflammatory drugs also leading to drug-induced toxic/adverse effects ${ }^{4}$. Hence, researchers keep focusing on natural resources for identification and evaluation of safe drugs with limited adverse effects.

The Lichens (a symbiotic organism) belong to the group of epiphytes which have an aptitude to persist on any substratum or geographical region ${ }^{5}$. The lichens that survived particularly or associated on the mangroves are named as manglicolous lichens ${ }^{6}$. Throughout ages, lichens are used for the treatment of several diseases due to its unique survival and their bioactive secondary metabolites. Lichen and their secondary metabolites exert a diverse range of pharmacological actions mainly anti-inflammatory and cytotoxic effects ${ }^{7}$. Especially, manglicolous lichens show difference in their biological components \& actions than normal lichens due to stressed physiological adaptation towards the intertidal zone i.e., having both the marine and freshwater environment ${ }^{6}$. So, the researchers have gained interest in the biological screening of particularly manglicolous lichens. Till date, there are a few pharmacological evaluation reports exist on the manglicolous lichens ${ }^{7}$.

Dirinaria genus contains 29 species distributed across the world. The pharmacological screening of this genus found to have radical scavenging, antimicrobial and insecticidal effects ${ }^{8}$. On the other hand, Ramalina genus has about 246 species distributed around the world, of which only 118 species were investigated for their chemical and biological studies. A diversity of secondary metabolites were isolated, includes dibenzofuran derivatives like usnic acid, depsides, depsidones, fatty acids, sterols and monocyclic aromatic compounds. Moreover, the biological screening of this genus results in identification of antioxidant, anti-inflammatory, anticancer, antimicrobial activities ${ }^{9}$. The present study was performed to evaluate the in vitro anti-inflammatory and cytotoxicity properties of two mangrove associated lichens namely Dirinaria consimilis and Ramalina leiodea using standard procedures and protocols.

\section{MATERIALS AND METHODS}

\subsection{Collection}

The specimens of mangrove lichen, Dirinaria consimilis (Stirton) D. D. Awasthi was collected on the bark of mangrove plant, Excoecaria agallocha from Vainateya Island, Godavari estuary, Andhra Pradesh,

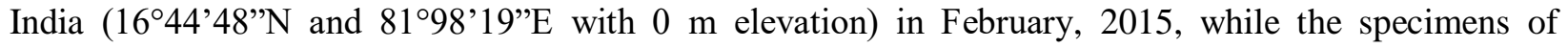
mangrove lichen, Ramalina leiodea ( $\mathrm{Nyl}$.) Nyl was collected on the twigs of mangrove plant, Ceriops decandra from Bhitharkanika Island, Rajnagar, Orissa, India $\left(20^{\circ} 74^{\prime} \mathrm{N}\right.$ and $86^{\circ} 87^{\prime} \mathrm{E}$ with $0 \mathrm{~m}$ elevation) in March, 2016. Both the mangrove associated lichens, Dirinaria consimilis and Ramalina leiodea were authenticated by Dr. D. K. Upreti, CSIR-National Botanical Research Institute (NBRI), Lucknow and deposited at Lichen herbarium, CSIR-NBRI, Lucknow, India with accession numbers 15-027173 and 16027175, respectively. 


\subsection{Extraction}

The lichen extraction is based on the modified procedures of Jug et al., $2017^{10}$ and Usui et al., $2017^{11}$. The lichen specimens collected from the twigs of respective mangrove plants were shade-dried. The dried lichen materials were powdered using blender and about $50 \mathrm{~g}$ of each mangrove associated lichen material was extracted thrice with ethanol-water (1:1) at room temperature. The mixture was filtered through muslin cloth and evaporated under reduced pressure to obtain hydro alcoholic extracts of Dirinaria consimilis (Dc-HA, $5.45 \mathrm{~g}$ ) and Ramalina leiodea (RI-HA, 6.21 g). These hydro alcoholic extracts were re-extracted with solvents (chloroform, ethyl acetate, acetone and methanol) of increased polarity and the obtained respective solvent extract was filtered through muslin cloth and concentrated in vacuum to obtain dry extracts of $D$. consimilis i.e., chloroform (DC, $956 \mathrm{mg}$ ), ethyl acetate (DE, $315 \mathrm{mg}$ ), acetone (DA, $256 \mathrm{mg}$ ) and methanol (DM, $1.2 \mathrm{~g}$ ); $R$. leiodea i.e., chloroform (RC, $225 \mathrm{mg}$ ), ethyl acetate (RE, $801 \mathrm{mg}$ ), acetone (RA, $448 \mathrm{mg}$ ) and methanol (RM, $1.45 \mathrm{~g}$ ) extracts, which were stored in amber coloured vials and preserved at $4^{\circ} \mathrm{C}$ till further use.

2.3 In vitro anti-inflammatory assay

Protein denaturation method was employed ${ }^{12}$ for the determination of in vitro anti-inflammatory activity for extracts and its isolates. Bovine serum albumin was used in this study. The protein was solubilized to $1 \%$ concentration using sodium phosphate buffer $(50 \mathrm{mM}, \mathrm{pH} 6.4)$. To $0.2 \mathrm{ml}$ of prepared protein, different concentration (i.e., $0.1,0.2,0.4,0.6,0.8,1.0 \mathrm{mg} / \mathrm{mL}$ ) of test sample/standard drug (Indomethacin, Indo) were added and make up the final volume to $5 \mathrm{~mL}$ with buffer, incubated at $37^{\circ} \mathrm{C}$ for $20 \mathrm{~min}$ and then heated to $95^{\circ} \mathrm{C}$ for $20 \mathrm{~min}$. After cooling, the turbidity was measured at $660 \mathrm{~nm}$ by using UV-Visible Spectrophotometer (Model SL 210, Elico India Ltd.). The experiment was performed in triplicate and average values (Mean $\pm \mathrm{SD}$ ) were reported. The percentage inhibition of protein denaturation was calculated as follows

Percentage inhibition $=[(\mathrm{C}-\mathrm{S}) / \mathrm{C}] \times 100$, Where $C$ is absorbance of Control, $S$ is absorbance of Sample

\subsection{Cytotoxicity assay}

\subsubsection{Cancer Cell lines}

MCF-7 (Breast), DLD-1 (Colon), HeLa (Cervical), FADU (Head \& Neck), A549 (Lung) and normal human mammary epithelial (NHME) cell lines were kindly provided by National Centre for Cell Science, Pune. The cancer cells were maintained in MEM media (containing 10\% fetal calf serum, 5\% mixture of penicillin (100 units) and streptomycin $(100 \mu \mathrm{g} / \mathrm{mL})$ in presence of $5 \%$ carbon dioxide incubator having $90 \%$ humidity at $37^{\circ} \mathrm{C}$ for $72 \mathrm{~h}$.

\subsubsection{Cell Growth Medium}

All the cancer cell lines were maintained in minimal essential medium (MEM) (adjusted to 10\% (v/v) FBS, $1.5 \mathrm{~g} / \mathrm{mL} \mathrm{NaHCO}_{3}, 0.1 \mathrm{mM}$ MEM non-essential amino acids and $1 \mathrm{mM}$ sodium pyruvate). Three days prior to performing assay, the cells were washed with sterilized PBS and grown using MEM media (supplemented with $0.25 \%$ trypsin in versene-EDTA and 10\% FBS) and mixed to obtain homogeneous suspension of cells. 
The suspension was taken in a sterilized polypropylene tube and the cell concentration in each well was determined by hematocytochameter chamber under a microscope using $0.4 \%$ trypan blue solution. The minimal seed density must be $1 \times 10^{4}$ cells per.

\subsubsection{Sample Preparation}

Initially, for primary screening all the crude extracts were dissolved in DMSO to $100 \mathrm{mg} / \mathrm{mL}$. The active extracts $(<50 \%$ inhibition) were further screened at 3.12, 6.25, 12.5, 25, 50, 75 and $100 \mu \mathrm{g} / \mathrm{mL}$ and their $\mathrm{IC}_{50}$ values were determined. The doxorubicin $(10 \mu \mathrm{g} / \mathrm{mL})$ and DMSO were used as a standard and control respectively.

\subsubsection{Sulforhodamine B (SRB) Colorimetric assay}

The SRB assay ${ }^{13}$ is based on the estimation of cellular protein content. The prepared samples were taken in 96-well tissue-culture plate and added $190 \mu \mathrm{L}$ screened ideal cell suspension and mixed occasionally and incubate at $37^{\circ} \mathrm{C}$ with $5 \% \mathrm{CO}_{2}$ and $90 \%$ relative humidity for $3 \mathrm{~h}$. Then add $100 \mu \mathrm{L}$ cold TCA to each well and incubate at $4^{\circ} \mathrm{C}$ for $1 \mathrm{~h}$. After that the plates were gently washed using water, dried using blow dryer and air-dried at room temperature. To each completely dried well, add $100 \mu \mathrm{L}$ of $0.057 \%$ SRB solution, kept aside for $30 \mathrm{~min}$ and quickly rinse with $1 \%$ acetic acid. To the dried plate add $200 \mu \mathrm{L}$ of 10 $\mathrm{mM}$ Tris base $(\mathrm{pH} 10.5)$ solution, shake for $5 \mathrm{~min}$ and measure the OD at $510 \mathrm{~nm}$. The blank contains only medium while the control has only cancer cells with no test samples. The experiment was performed in triplicate and average values (Mean $\pm \mathrm{SD}$ ) were reported. The percentage of growth inhibition was calculated using below formula.

$\%$ Growth inhibition $=100-[\mathrm{S} / \mathrm{C}] \times 100$, Where $S$ is mean OD value of sample, $C$ is mean OD value of control

\subsection{Statistical Analysis}

All the results were expressed as mean \pm SD and analyzed by using Two-way ANOVA followed by Dunnett's multiple comparison tests. All groups were compared with control.

Table 1: In vitro anti-inflammatory activity of all extracts of D. consimilis and $R$. Leiodea

\begin{tabular}{ccccccc}
\hline \multirow{2}{*}{ Sample } & \multicolumn{5}{c}{ Percentage inhibition at different concentrations $(\%)^{*}$} \\
\cline { 2 - 6 } & $0.1 \mathrm{mg} / \mathrm{mL}$ & $0.2 \mathrm{mg} / \mathrm{mL}$ & $0.4 \mathrm{mg} / \mathrm{mL}$ & $0.6 \mathrm{mg} / \mathrm{mL}$ & $0.8 \mathrm{mg} / \mathrm{mL}$ & $1 \mathrm{mg} / \mathrm{mL}$ \\
\hline DC & $15.94 \pm 1.03$ & $16.67 \pm 0.61^{*}$ & $17.39 \pm 1.13^{*}$ & $22.23 \pm 0.29^{*}$ & $23.67 \pm 1.15^{*}$ & $24.87 \pm 1.93$ \\
DE & $23.67 \pm 1.15$ & $24.88 \pm 1.92^{*}$ & $33.82 \pm 2.64$ & $42.02 \pm 0.89^{*}$ & $50.9 \pm 1.05^{*}$ & $63.52 \pm 1.67$ \\
DA & $18.12 \pm 2.59$ & $22.70 \pm 1.53^{*}$ & $32.13 \pm 1.56^{*}$ & $42.27 \pm 0.53^{*}$ & $51.20 \pm 1.73$ & $65.70 \pm 0.48^{*}$ \\
DM & $14.97 \pm 1.59$ & $18.35 \pm 1.75^{*}$ & $22.46 \pm 3.77$ & $23.42 \pm 2.95$ & $29.46 \pm 1.86$ & $38.88 \pm 1.89$ \\
RC & $20.04 \pm 0.83$ & $30.19 \pm 3.24$ & $37.19 \pm 2.81$ & $46.85 \pm 1.99$ & $52.89 \pm 1.55^{*}$ & $67.63 \pm 2.85$ \\
RE & $32.12 \pm 0.56$ & $41.54 \pm 0.59^{*}$ & $54.58 \pm 2.97$ & $63.04 \pm 3.48$ & $74.63 \pm 1.68$ & $82.36 \pm 3.15$ \\
RA & $29.71 \pm 2.14$ & $43.71 \pm 3.81$ & $61.83 \pm 3.75$ & $74.15 \pm 2.59$ & $83.57 \pm 1.88$ & $89.85 \pm 3.07$ \\
RM & $15.94 \pm 2.03$ & $19.80 \pm 2.76$ & $23.18 \pm 2.41$ & $30.67 \pm 1.33^{*}$ & $37.68 \pm 1.16^{*}$ & $44.68 \pm 2.99$ \\
Indo & $46.91 \pm 2.60$ & $61.52 \pm 2.12$ & $73.91 \pm 0.45^{*}$ & $81.15 \pm 2.29$ & $87.43 \pm 1.35$ & $94.45 \pm 0.49$ \\
\hline
\end{tabular}

$*_{n=3}$, Mean $\pm S D$, two-way ANOVA followed by Dunnett's multiple comparison test, * $p<0.05 ; D C$ - Chloroform extract of D. consimilis; DEEthyl acetate extract of D. consimilis; DA-Acetone extract of D. consimilis; DM- Methanol of D. consimilis; RC-Chloroform extract of R. leiodea; RE-Ethyl acetate extract of R. leiodea; RA-Acetone extract of R. leiodea; RM-Methanol of R. leiodea; Indo-Indomethacin (Standard Drug) 
Table S1: Cytotoxicity studies of ethyl acetate extract of Dirinaria consimilis (DE) on different cancer cell lines

\begin{tabular}{|c|c|c|c|c|c|c|c|}
\hline \multirow{2}{*}{ Sample } & \multicolumn{7}{|c|}{ Percentage inhibition (\%) at different concentrations $(\mu \mathrm{g} / \mathrm{mL}) *$} \\
\hline & 3.12 & 6.25 & 12.5 & 25 & 50 & 75 & 100 \\
\hline$M C F-7$ & $28.68 \pm 0.75$ & $36.34 \pm 1.37$ & $50.38 \pm 1.79$ & $60.42 \pm 0.46^{*}$ & $74.69 \pm 0.67 *$ & $83.60 \pm 1.12$ & $93.35 \pm 0.72 *$ \\
\hline$D L D-1$ & $16.85 \pm 0.10$ & $26.23 \pm 0.75^{*}$ & $38.91 \pm 0.52 *$ & $56.52 \pm 0.37 *$ & $71.06 \pm 0.32 *$ & $84.84 \pm 1.28$ & $96.20 \pm 0.47 *$ \\
\hline $\mathrm{HeLa}$ & $24.79 \pm 0.79$ & $35.53 \pm 1.17$ & $46.95 \pm 1.01$ & $54.15 \pm 1.72$ & $60.19 \pm 0.56^{*}$ & $77.57 \pm 1.11$ & $89.66 \pm 0.83^{*}$ \\
\hline $\begin{array}{c}F A D U \\
A 549\end{array}$ & $\begin{array}{c}6.50 \pm 0.23 \\
11.45 \pm 0.17\end{array}$ & $\begin{array}{l}25.10 \pm 0.88^{*} \\
22.09 \pm 0.28^{*}\end{array}$ & $\begin{array}{l}36.58 \pm 0.26^{*} \\
33.67 \pm 0.11^{*}\end{array}$ & $\begin{array}{c}50.75 \pm 1.05 \\
49.86 \pm 0.60 *\end{array}$ & $\begin{array}{c}68.30 \pm 1.71 \\
61.05 \pm 0.46^{*}\end{array}$ & $\begin{array}{l}86.34 \pm 0.39^{*} \\
74.94 \pm 0.24 *\end{array}$ & $\begin{array}{l}97.57 \pm 1.90 \\
85.50 \pm 1.39\end{array}$ \\
\hline
\end{tabular}

Table S2: Cytotoxicity studies of acetone extract of Dirinaria consimilis (DA) on different cancer cell lines

\begin{tabular}{cccccccc}
\hline \multirow{2}{*}{ Sample } & \multicolumn{7}{c}{ Percentage inhibition (\%) at different concentrations $(\mu \mathrm{g} / \mathrm{mL})^{*}$} \\
\cline { 2 - 8 } & 3.12 & 6.25 & 12.5 & 25 & 50 & 75 & 100 \\
\hline MCF-7 & $13.75 \pm 0.40$ & $28.30 \pm 0.88^{*}$ & $34.38 \pm 0.21^{*}$ & $49.89 \pm 0.76^{*}$ & $64.15 \pm 0.87^{*}$ & $76.06 \pm 1.40$ & $87.06 \pm 0.40^{*}$ \\
DLD-1 & $29.06 \pm 0.69$ & $40.76 \pm 1.25$ & $52.79 \pm 1.32$ & $62.43 \pm 1.23$ & $73.69 \pm 0.79^{*}$ & $83.22 \pm 0.42^{*}$ & $97.42 \pm 0.45^{*}$ \\
HeLa & $33.25 \pm 1.13$ & $42.29 \pm 0.21^{*}$ & $51.00 \pm 0.83^{*}$ & $63.25 \pm 0.57^{*}$ & $72.74 \pm 0.76^{*}$ & $81.62 \pm 0.67^{*}$ & $94.79 \pm 1.54$ \\
$F A D U$ & $3.63 \pm 0.55$ & $13.95 \pm 0.47^{*}$ & $33.90 \pm 1.57$ & $46.14 \pm 1.06$ & $67.96 \pm 0.74^{*}$ & $77.19 \pm 1.13$ & $97.32 \pm 0.96^{*}$ \\
$A 549$ & $19.44 \pm 0.29$ & $28.59 \pm 0.27^{*}$ & $39.43 \pm 0.52^{*}$ & $58.00 \pm 0.43^{*}$ & $69.31 \pm 0.64^{*}$ & $80.69 \pm 0.77^{*}$ & $92.61 \pm 1.77$ \\
\hline
\end{tabular}

$*_{n=3}$, Mean $\pm S D$, two-way ANOVA followed by Dunnett's multiple comparison test, ${ }^{*} p<0.05$; MCF-7: Breast cancer cell line, DLD-1: Colon cancer cell line; HeLa: Cervical cancer cell line; FADU: Head \& Neck cancer cell line; A549: Lung cancer cell line

Table S3: Cytotoxicity studies of chloroform extract of Ramalina leiodea (RC) on different cancer cell lines

\begin{tabular}{cccccccc}
\hline \multirow{2}{*}{ Sample } & \multicolumn{7}{c}{ Percentage inhibition $(\%)$ at different concentrations $(\mu \mathrm{g} / \mathrm{mL}) *$} \\
\cline { 2 - 8 } & 3.12 & 6.25 & 12.5 & 25 & 50 & 75 & 100 \\
\hline MCF-7 & $17.19 \pm 0.75$ & $23.33 \pm 1.71$ & $32.69 \pm 1.28$ & $39.92 \pm 2.50$ & $49.81 \pm 1.26$ & $56.31 \pm 1.30$ & $71.25 \pm 0.10^{*}$ \\
$D L D-1$ & $12.28 \pm 0.48$ & $27.37 \pm 1.74$ & $40.12 \pm 2.00$ & $49.34 \pm 1.56$ & $61.73 \pm 0.60^{*}$ & $74.22 \pm 0.23^{*}$ & $87.01 \pm 0.36^{*}$ \\
$F A D U$ & $3.05 \pm 0.06$ & $6.47 \pm 0.84^{*}$ & $13.66 \pm 0.4^{*} 5$ & $26.80 \pm 2.06$ & $43.35 \pm 0.51^{*}$ & $59.97 \pm 0.71^{*}$ & $70.21 \pm 0.22^{*}$ \\
A549 & $3.12 \pm 0.68$ & $14.15 \pm 1.44$ & $21.08 \pm 1.21$ & $29.19 \pm 1.88$ & $38.00 \pm 1.60$ & $45.39 \pm 1.02$ & $57.25 \pm 1.05$ \\
\hline
\end{tabular}

$*_{n}=3$, Mean $\pm S D$, two-way ANOVA followed by Dunnett's multiple comparison tests, ${ }^{*} p<0.05 ;$ MCF-7: Breast cancer cell line, DLD-1: Colon cancer cell line; FADU: Head \& Neck cancer cell line; A549: Lung cancer cell line

Table S4: Cytotoxicity studies of ethyl acetate extract of Ramalina leiodea $(\mathbf{R E})$ on different cancer cell lines

\begin{tabular}{cccccccc}
\hline \multirow{2}{*}{ Sample } & \multicolumn{7}{c}{ Percentage inhibition $(\%)$ at different concentrations $(\mu g / m L) *$} \\
\cline { 2 - 8 } & 3.12 & 6.25 & 12.5 & 25 & 50 & 75 & 100 \\
\hline MCF-7 & $13.23 \pm 0.61$ & $24.79 \pm 1.23$ & $34.60 \pm 2.30$ & $46.51 \pm 2.42$ & $62.01 \pm 1.98$ & $78.26 \pm 0.87^{*}$ & $97.30 \pm 2.31$ \\
DLD-1 & $16.12 \pm 3.00$ & $28.63 \pm 3.91$ & $41.39 \pm 2.17$ & $53.24 \pm 1.49$ & $60.44 \pm 1.92$ & $80.33 \pm 0.85^{*}$ & $94.79 \pm 0.87^{*}$ \\
HeLa & $48.42 \pm 0.87$ & $53.13 \pm 0.72^{*}$ & $60.64 \pm 1.45$ & $72.56 \pm 2.49$ & $81.63 \pm 0.12^{*}$ & $88.45 \pm 1.58$ & $95.32 \pm 0.68^{*}$ \\
$F A D U$ & $25.88 \pm 3.71$ & $31.94 \pm 1.49$ & $49.26 \pm 0.31^{*}$ & $55.14 \pm 1.74$ & $66.32 \pm 2.25$ & $79.05 \pm 0.62^{*}$ & $97.80 \pm 1.73$ \\
$A 549$ & $21.41 \pm 0.83$ & $35.16 \pm 0.11^{*}$ & $40.85 \pm 1.35$ & $54.06 \pm 0.93^{*}$ & $68.16 \pm 1.93$ & $78.99 \pm 1.65$ & $90.79 \pm 0 . .77^{*}$ \\
\hline
\end{tabular}

$*_{n}=3$, Mean $\pm S D$, two-way ANOVA followed by Dunnett's multiple comparison test, ${ }^{*} p<0.05 ;$ MCF-7: Breast cancer cell line, DLD-1: Colon cancer cell line; HeLa: Cervical cancer cell line; FADU: Head \& Neck cancer cell line; A549: Lung cancer cell line 
Table S5: Cytotoxicity studies of acetone extract of Ramalina leiodea (RA) on different cancer cell lines

\begin{tabular}{cccccccc}
\hline \multirow{2}{*}{ Sample } & \multicolumn{7}{c}{ Percentage inhibition (\%) at different concentrations $(\mu \mathrm{g} / \mathrm{mL}) *$} \\
\cline { 2 - 8 } & 3.12 & 6.25 & 12.5 & 25 & 50 & 75 & 100 \\
\hline MCF-7 & $28.38 \pm 0.99$ & $40.21 \pm 2.08$ & $51.04 \pm 2.48$ & $63.17 \pm 2.27$ & $74.02 \pm 1.06^{*}$ & $81.37 \pm 1.75$ & $94.23 \pm 1.05^{*}$ \\
DLD-1 & $18.43 \pm 2.11$ & $28.03 \pm 1.06^{*}$ & $42.49 \pm 1.39^{*}$ & $50.56 \pm 1.97$ & $67.61 \pm 1.16^{*}$ & $83.86 \pm 1.15$ & $98.84 \pm 0.53^{*}$ \\
HeLa & $14.50 \pm 1.61$ & $18.50 \pm 1.48$ & $29.14 \pm 1.77$ & $42.31 \pm 2.00$ & $60.53 \pm 2.28$ & $72.97 \pm 0.98^{*}$ & $89.96 \pm 1.41$ \\
$F A D U$ & $16.53 \pm 0.34$ & $20.96 \pm 1.89$ & $41.06 \pm 1.75$ & $56.76 \pm 3.29$ & $66.32 \pm 2.25$ & $79.05 \pm 0.62^{*}$ & $97.80 \pm 1.73$ \\
A549 & $13.15 \pm 1.41$ & $19.58 \pm 1.12^{*}$ & $31.49 \pm 1.76$ & $47.63 \pm 2.12$ & $62.14 \pm 1.49$ & $76.96 \pm 1.18$ & $88.08 \pm 1.59$ \\
\hline
\end{tabular}

$*_{n}=3$, Mean $\pm S D$, two-way ANOVA followed by Dunnett's multiple comparison test, * $p<0.05$; MCF-7: Breast cancer cell line, DLD-1: Colon cancer cell line; HeLa: Cervical cancer cell line; FADU: Head \& Neck cancer cell line; A549: Lung cancer cell line

Moreover, the concentration of RA, RE, RC, DA and DE needed for 50\% inhibition of bovine albumin protein denaturation were found to be $268,330,700,780$ and $800 \mu \mathrm{g} / \mathrm{mL}$, respectively, while standard (Indo) was $120 \mu \mathrm{g} / \mathrm{mL}$ (Fig.1). From the results it can be concluded that the mangrove associated lichen, R. leiodea has potent in vitro anti-inflammatory activity when compared to the D. consimilis.

\section{RESULTS AND DISCUSSION}

\subsection{In vitro Anti-inflammatory activity}

The in vitro anti-inflammatory capability of all $D$. consimilis and $R$. leiodea extracts were initially subjected to protein denaturation method ${ }^{12}$ using concentrations from 0.1 to $1 \mathrm{mg} / \mathrm{mL}$ for standard (indomethacin) as well as extracts and data is tabulated in Table 1. The data evident that the DE, DA, RC, RE and RA revealed good in vitro anti-inflammatory profile. (Table 1). Among all tested samples, the $\mathbf{R A}$ and RE (at $1 \mathrm{mg} / \mathrm{mL}$ ) depicted prominent inhibitory activity against protein denaturation which is almost nearer to the standard drug (Indo, $1 \mathrm{mg} / \mathrm{mL}$ ) (Table 1). At $1 \mathrm{mg} / \mathrm{mL}$ concentration, the percentage inhibition of bovine albumin protein denaturation for $\mathbf{R A}$ and $\mathbf{R E}$ were noticed to be $89.85 \pm 3.07$ and $82.36 \pm 3.15 \%$, respectively, while standard with $94.45 \pm 0.49 \%$ (Table 1). In addition, the RC, DA and DE at $1 \mathrm{mg} / \mathrm{mL}$ concentration exhibited $67.63 \pm 2.85,65.70 \pm 0.48$ and $63.52 \pm 1.67 \%$ inhibition of protein denaturation, respectively.

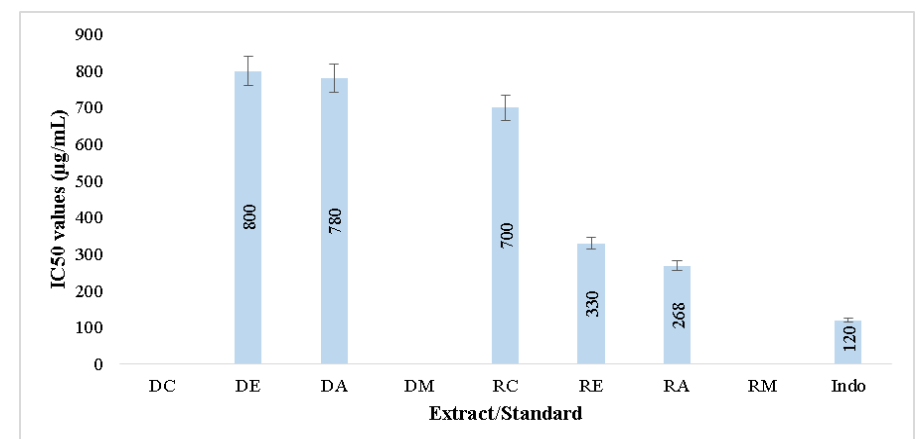

Fig.1: Inhibitory effects of all extracts of $D$. consimilis and $R$. leiodea against protein denaturation.

[DC-Chloroform extract of D. consimilis; DE-Ethyl acetate extract of D. consimilis; DA-Acetone extract of D. consimilis; DM- Methanol of D. consimilis; $R C$ - Chloroform extract of $R$. leiodea; RE-Ethyl acetate extract of R. leiodea; RA-Acetone extract of R. leiodea; RM- Methanol of $R$. leiodea; Indo- Indomethacin (Standard Drug)] 


\subsection{Cytotoxicity studies}

Initially, the cytotoxicity studies of all the prepared $D$. consimilis and $R$. leiodea extracts were screened against different human cancer cell lines (MCF-7, DLD-1, HeLa, FADU and A549) at $100 \mu \mathrm{g} / \mathrm{mL}$ concentration by SRB assay ${ }^{13}$ using doxorubicin $(10 \mu \mathrm{g} / \mathrm{mL})$ as standard and results of percentage cells growth inhibition was illustrated in Table 2. Simultaneously, the in vitro toxicity studies of all extracts were tested on normal human mammary epithelial (NHME) cell line.

Table 2: Cytotoxicity activity of all extracts of $D$. consimilis and $R$. leiodea against different cancer cell lines.

\begin{tabular}{ccccccc}
\hline \multirow{2}{*}{ Sample } & \multicolumn{7}{c}{ Percentage inhibition at $100 \mu \mathrm{g} / \mathrm{mL}$ concentration (\%)* } \\
\cline { 2 - 6 } & MCF-7 & DLD-1 & HeLa & FADU & A549 & NHME \\
\hline DC & $9.31 \pm 0.47^{*}$ & $6.82 \pm 0.04^{*}$ & $0.36 \pm 0.08^{*}$ & $3.14 \pm 0.64^{*}$ & $9.08 \pm 0.56^{*}$ & $0.15 \pm 0.00^{*}$ \\
DE & $93.34 \pm 0.70^{*}$ & $96.20 \pm 0.47^{*}$ & $89.66 \pm 0.86^{*}$ & $97.57 \pm 1.90$ & $85.50 \pm 1.39$ & $0.50 \pm 0.10^{*}$ \\
DA & $87.03 \pm 0.36$ & $97.42 \pm 0.45^{*}$ & $94.79 \pm 1.54$ & $97.32 \pm 0.96^{*}$ & $92.61 \pm 1.77$ & $0.74 \pm 0.02^{*}$ \\
DM & $0.74 \pm 0.13^{*}$ & $6.87 \pm 0.95^{*}$ & $0.79 \pm 0.70^{*}$ & $3.05 \pm 0.06^{*}$ & $5.62 \pm 0.79^{*}$ & $1.04 \pm 0.13^{*}$ \\
RC & $71.19 \pm 0.02^{*}$ & $87.01 \pm 0.36^{*}$ & $40.86 \pm 0.94^{*}$ & $70.21 \pm 0.22^{*}$ & $57.25 \pm 1.05$ & $6.53 \pm 0.31^{*}$ \\
RE & $97.30 \pm 2.31$ & $94.79 \pm 0.87^{*}$ & $95.32 \pm 0.68^{*}$ & $97.93 \pm 0.35^{*}$ & $90.79 \pm 0.77^{*}$ & $8.42 \pm 0.09^{*}$ \\
RA & $94.21 \pm 1.06$ & $98.84 \pm 0.53$ & $89.96 \pm 1.41$ & $97.80 \pm 1.73$ & $88.08 \pm 1.59$ & $9.20 \pm 0.67^{*}$ \\
RM & $9.67 \pm 0.22^{*}$ & $2.32 \pm 0.05^{*}$ & $7.47 \pm 0.60^{*}$ & $7.47 \pm 0.74^{*}$ & $8.34 \pm 0.42^{*}$ & $2.30 \pm 0.96^{*}$ \\
Doxorubicin $(10 \mu \mathrm{g} / \mathrm{mL})$ & $81.25 \pm 1.56$ & $72.67 \pm 0.21$ & $85.55 \pm 1.31$ & $98.50 \pm 1.21$ & $77.92 \pm 0.41^{*}$ & $1.20 \pm 0.81^{*}$ \\
\hline
\end{tabular}

$*_{n}=3$, Mean $\pm S D$, two-way ANOVA followed by Dunnett's multiple comparison test, ${ }^{*} p<0.05 ; \boldsymbol{D C}$ - Chloroform extract of D. consimilis; $\boldsymbol{D E}$ Ethyl acetate extract of D. consimilis; DA-Acetone extract of D. consimilis; DM-Methanol of D. consimilis; RC-Chloroform extract of R. leiodea; $\boldsymbol{R E}$ - Ethyl acetate extract of R. leiodea; RA-Acetone extract of R. leiodea; $\boldsymbol{R M}$ - Methanol of R. leiodea; MCF-7: Breast cancer cell line, DLD-1: Colon cancer cell line; HeLa: Cervical cancer cell line; FADU: Head \& Neck cancer cell line; A549: Lung cancer cell line; NHME: Normal Human Mammary Epithelial cell lines

The outcomes of the SRB assay illustrates that the DE, DA, RC, RE and RA extracts showed good degree of specificity towards the tested panel of cancer cell lines, while rest extracts (DC, DM and RM) showed very low degree of specificity (Table S1-S5, Table 2). At $100 \mu \mathrm{g} / \mathrm{mL}$ concentration, the ethyl acetate (DE and RE) and acetone (DA and RA) extracts of both the lichens exhibited potent percentage of cells growth inhibition on all the tested human cancer cell lines (except on FADU) than that of the standard (doxorubicin) at $10 \mu \mathrm{g} / \mathrm{mL}$ (Table 2).

The RE, RA, DE, DA and RC showed prominent specificity for the MCF-7 with percentage of cells growth inhibition of $97.30 \pm 2.31,94.21 \pm 1.06,93.34 \pm 0.70,87.03 \pm 0.36$ and $71.19 \pm 0.02 \%$ respectively at $100 \mu \mathrm{g} / \mathrm{mL}$ concentration, while standard with $81.25 \pm 1.56 \%$ at $10 \mu \mathrm{g} / \mathrm{mL}$ (Table 2). Similarly, at 100 $\mu \mathrm{g} / \mathrm{mL}$ concentration the RA, DA, DE, RE and RC exhibited better percentage of growth inhibition on DLD-1 cancer cell lines with $98.84 \pm 0.53,97.42 \pm 0.45,96.20 \pm 0.47,94.79 \pm 0.87$ and $87.01 \pm 0.36 \%$ respectively, whereas standard with $72.67 \pm 0.21 \%$ at $10 \mu \mathrm{g} / \mathrm{mL}$ (Table S1-S5, Table 2).

The percentage cells growth of HeLa cancer cell line was potently inhibited by RE, DA, RA and DE $(100 \mu \mathrm{g} / \mathrm{mL})$ with $95.32 \pm 0.68,94.79 \pm 1.54,89.96 \pm 1.41$ and $89.66 \pm 0.86 \%$, respectively, while standard $(10 \mu \mathrm{g} / \mathrm{mL}$ ) with $85.55 \pm 1.31 \%$ (Table S1-S2; Table S4-S5, Table 2). 
Similarly, the FADU cancer cell line was significantly inhibited by RE, RA, DE, DA and RC with $97.93 \pm 0.35,97.80 \pm 1.73,97.57 \pm 1.90,97.32 \pm 0.96$ and $70.21 \pm 0.22 \%$, besides standard with $98.50 \pm 1.21 \%$ (Table S1-S5, Table 2). Furthermore, the cells growth of A549 cancer cell line was prominently inhibited by DA, RE, RA, DE and RC $(100 \mu \mathrm{g} / \mathrm{mL})$ with $92.61 \pm 1.77,90.79 \pm 0.77,88.08 \pm 1.59,85.50 \pm 1.39$ and $57.25 \pm 1.05 \%$, respectively, whereas standard $(10 \mu \mathrm{g} / \mathrm{mL}$ ) with $77.92 \pm 0.41 \%$ (Table S1-S5, Table 2).

On the other hand, all the tested extracts depicted less degree of specificity towards NHME cell lines at $100 \mu \mathrm{g} / \mathrm{mL}$ concentrations. The percentage cells growth inhibition of $D$. consimilis and $R$. leiodea extracts on NHME cell lines at $100 \mu \mathrm{g} / \mathrm{mL}$ were in the order: DC $(0.15 \pm 0.00 \%)<$ DE $(0.50 \pm 0.10 \%)<$ DA $(0.74 \pm 0.02 \%)<\mathbf{D M}(1.04 \pm 0.13 \%)<\mathbf{R M}(2.30 \pm 0.96 \%)<\mathbf{R C}(6.53 \pm 0.31 \%)<\mathbf{R E}(8.42 \pm 0.09 \%)<\mathbf{R A}$ $(9.20 \pm 0.67 \%)$, besides, standard with $1.20 \pm 0.81 \%$ at $10 \mu \mathrm{g} / \mathrm{mL}$ concentration (Table 2$)$. This low degree of specificity towards NHME cells indicates that all the extracts were less toxic towards normal human cells. From the data it is also found that the D. consimilis is less toxic than the R. leiodea.

Considering the initial cytotoxicity screening of all the extracts, further evaluation of IC50 values were performed for those solvent extract (DE, DA, RC, RE and RA) which showed good specificity towards cancer cell lines i.e., more than $50 \%$ cells growth inhibition. Among all the tested samples, the better $\mathrm{IC}_{50}$ values was determined by $\mathbf{R E}$ of $4.5 \mu \mathrm{g} / \mathrm{mL}$ on HeLa (Fig.2). The DE showed $\mathrm{IC}_{50}$ value of 12.25, 20.25, 18.02, 24.0 and $25.4 \mu \mathrm{g} / \mathrm{mL}$ on MCF-7, DLD-1, HeLa, FADU and A549, respectively, whereas DA depicted IC $_{50}$ value of 25.01, 11.02, 11.79, 30.0 and $19.75 \mu \mathrm{g} / \mathrm{mL}$, respectively (Fig.2).

In addition, the $\mathbf{R C}$ showed $\mathrm{IC}_{50}$ value of $50.09,25.04,70.4$ and $85.5 \mu \mathrm{g} / \mathrm{mL}$ on MCF-7, DLD-1, FADU and $\mathrm{A} 549$, respectively (Fig.2). The $\mathrm{IC}_{50}$ values for $\mathbf{R E}$ were found to be 31.9, 21.5, 4.5, 13.05 and 21.9 $\mu \mathrm{g} / \mathrm{mL}$ on MCF-7, DLD-1, HeLa, FADU and A549, respectively, while RA depicted 11.95, 23.75, 35.5, 19.75 and $30.7 \mu \mathrm{g} / \mathrm{mL}$, respectively (Fig.2).

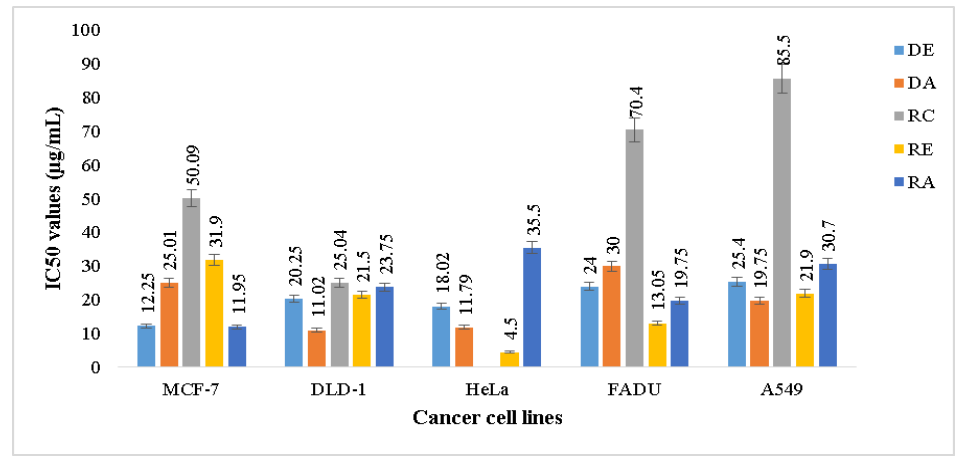

Fig.2 IC $_{50}$ values of DE, DA, RC, RE and RA extracts against panel of cancer cells.

[MCF-7: Breast cancer cell line, DLD-1: Colon cancer cell line; HeLa: Cervical cancer cell line; FADU: Head \& Neck cancer cell line; A549: Lung cancer cell line; $\boldsymbol{D E}$ - Ethyl acetate extract of D. consimilis; DA-Acetone extract of D. consimilis; $\boldsymbol{R C}$ - Chloroform extract of $R$. leiodea; $\boldsymbol{R E}$ - Ethyl acetate extract of R. leiodea; $\boldsymbol{R A}$-Acetone extract of R. leiodea] 
Hence, from the data it can be confirmed that the DE, DA, RC, RE and RA extracts was very active against Breast (MCF-7), Cervical (HeLa), Colon (DLD-1), Head \& Neck (FADU) and Lung (A549) cancer cell lines. In particularly, the DE and RA were more active against Breast cancer cell line, while DA and RC against Colon. Furthermore, the RE is very potently active against cervical cancer cell lines.

\section{CONCLUSION}

This is a preliminary report of in vitro anti-inflammatory and cytotoxicity profile of mangrove associated lichens, Dirinaria consimilis and Ramalina leiodea. In this study, the solvent extracts of both lichens were shown to inhibit protein denaturation and also cells growth inhibition against MCF-7, DLD1, HeLa, FADU and A549 cancer cell lines. Isolation and structural characterization of the pure secondary metabolites that elicited these activities are currently in progress in our laboratory. This study work shows that the both lichens, $D$. consimilis and $R$. leiodea has good amount of anti-inflammatory activity as well as inhibitory profile against cancer cell lines along with low degree of toxicity.

\section{Acknowledgement}

We thank the Ministry of Earth Sciences, India for the financial support (Grant No.: A.V. (1) / MOES2/DS/6/2007), the Directors of CSIR-CDRI and CSIR-NBRI (Lucknow, India) for providing the necessary facilities. No conflict of interest between any of the authors.

\section{References}

1. Tracey KJ. The inflammatory reflex. Nature 2002; 420: 853-859. CrossRef PMid:12490958

2. Ferrero-Miliani L., Nielsen O., Andersen PS., Girardin SE. Chronic inflammation: importance of NOD2 and NALP3 in interleukin-1 $\beta$ generation. Clinical and Experimental Immunology 2006; 147: 227-235.CrossRef

3. Kamath PR., Sunil D., Ajees AA., Pai KSR., Biswas S. N'-((2-(6-bromo-2-oxo-2H-chromen-3-yl)-1H-indol-3-yl) methylene) benzohydrazide as a probable $\mathrm{Bcl}-2 / \mathrm{Bcl}-\mathrm{xL}$ inhibitor with apoptotic and anti-metastatic potential. European Journal of Medicinal Chemistry 2016; 120: 134-147.CrossRef PMid:27187865

4. Govender T., Brand M. Adverse gastrointestinal bleeding associated with over-the-counter nonsteroidal antiinflammatory drug use: a cost study in two Gauteng public hospitals. South African Pharmaceutical Journal 2018; 85 : 65-71.

5. Nayaka S., Ingle KK., Bajpai R., Rawal JR., Upreti DK., Trivedi S. Lichens of Gujarat state, India with special reference to coastal habitats. Current Research in Environmental \& Applied Mycology 2013; 3: 222-229. CrossRef

6. Logesh AR., Kalaiselvam M., Upreti DK., Nayaka S., Karthiresan K. Mangroves - an abode for unique lichens. Cocasal Ecosystems of India - Special Publication 2013; 39-44.

7. Kumar J., Dhar P., Tayade AB., Gupta D., Chaurasia OP., Upreti DK., Arora R., Srivastava RB. Antioxidant capacities, phenolic profile and cytotoxic effects of Saxicolous lichens from Trans-Himalayan cold Desert of Ladakh. PLoS One 2014; 9: e98696. CrossRef PMid:24937759 PMCid:PMC4061001

8. Prashith KTR., Dhanya R., Dhatri R., Sunita CM., Onkarappa R., Vinayaka KS. Radical Scavenging, antimicrobial and insecticidal efficacy of Parmotrema cristiferum and Dirinaria applanata. Science, Technology and Arts Research Journal 2015; 4: 95-102. CrossRef

9. Moreira ASN., Braz-Filho R., Mussi-Dias V., Vieira IJC. Chemistry and biological activity of Ramalina lichenized fungi. Molecules 2015; 20: 8952-8987. CrossRef PMid:25996207 
10. Jug M., Karas O., Kosalec I. The influence of extraction parameters on antimicrobial activity of propolis extracts. Natural Product Communications 2017; 12(1): 47-50.

11. Usui A., Matsuo Y., Tanaka T., Ohshima K., Fukuda S., Mine T., Nakayama H., Ishimaru K. Ferulic acid esters of oligo-glucose from Allium macrostemon. Natural Product Communications 2017; 12(1): 89-91.

12. Buddana SK., Varanasi YVN., Shetty PR. Fibrinolytic, anti-inflammatory and anti-microbial properties of $\alpha-(1-3)-$ glucans produced from Streptococcus mutans (MTCC 497). Carbohydrate Polymers 2015; 115: 152-159. CrossRef PMid:25439880

13. Vichai V., Kirtikara K. Sulforhodamine B colorimetric assay for cytotoxicity screening. Nature Protocol 2006; 1 : 1112-1116 CrossRef PMid:17406391

Vinay Bharadwaj Tatipamula and Girija Sastry Vedula. In vitro anti-inflammatory and cytotoxicity studies of two mangrove associated lichens, Dirinaria consimilis and Ramalina leiodea extracts. Hygeia.J.D.Med 2018; 10(1):16-26.Available from http://www.hygeiajournal.com, DOI: 10.15254/H.J.D.Med.10.2018.174.

This is an Open Access article distributed in accordance with the Creative Commons Attribution Non Commercial (CC BY-NC 3.0) license, which permits others to share, distribute, remix, transform, build upon this work non-commercially, and license their derivative works on different terms, provided the original work is properly cited and the use is non-commercial 